\title{
Public green space quantity and distribution in Cairo, Egypt
}

\author{
Dalia Aly $^{1,2^{*}}$ id and Branka Dimitrijevic ${ }^{1}$
}

\author{
* Correspondence: dalia-aly-gaafar- \\ aly@strath.ac.uk; daliaali@eng.asu. \\ edu.eg \\ 'Department of Architecture, \\ Faculty of Engineering, University of \\ Strathclyde, 75 Montrose Street, \\ G11XJ, Glasgow, UK \\ ${ }^{2}$ Department of Architecture \\ Faculty of Engineering, Ain Shams \\ University, 1 Elsarayat Street, \\ Abbasiya, Cairo 11517, Egypt
}

\begin{abstract}
Green spaces are recognised as an important contributor in enhancing the quality of urban life. Many cities are now working on preserving and increasing their green spaces as a part of their sustainable development plans. Unfortunately, green spaces in Cairo are currently being marginalised and the city has been losing significant quantities of its already limited green spaces in favour of other developmental projects. This article analyses the quantities and distribution of existing green spaces in Cairo using official numerical data. The results show recent changes that happened between the years 2017 and 2020. The focus is on public green spaces: amenity green spaces between residential blocks, street green spaces, plant nurseries under public management and public parks. Finally, the trend of disappearing green spaces in Cairo is discussed. The discussion extends the comparison to include data from the years 2000 and 2006 to demonstrate the rapid changes happening in Cairo that are altering the city and affecting many of its residents. The problem of lack of data about green spaces is also examined in the discussion. Documenting green spaces areas and distribution in Cairo is important because no recent published data are available for decision-makers, researchers and planners. Data is also scattered between different sources because of the division of management responsibilities between different public agencies. A larger-scale project is required to accurately survey all green spaces in Cairo and create a comprehensive publicly accessible geographical database that documents all their types, quantities and distribution.
\end{abstract}

Keywords: Cairo, Green space, Public park, Urban inequality, Disparities, Development, Infrastructure

\section{Introduction}

The city of Cairo, in over a thousand years, had grown vastly in area, from around 7 $\mathrm{km}^{2}$ when founded as al-Fustat [23], to $840 \mathrm{~km}^{2}$ [27]. It has the highest number of inhabitants in Egypt-around 9.9 million-which represents 10\% of the Egyptian population [11]. It had gone through major transformations that gradually changed its urban character. Nowadays, Cairo is still subjected to rapid changes and both formal and informal development. The old urban core is still growing and attracting more population while new communities are expanding towards its desert boundaries with new districts and satellite cities. Through the process of urbanisation, Cairo has been losing

(c) The Author(s). 2022 Open Access This article is licensed under a Creative Commons Attribution 4.0 International License, which permits use, sharing, adaptation, distribution and reproduction in any medium or format, as long as you give appropriate credit to the original author(s) and the source, provide a link to the Creative Commons licence, and indicate if changes were made. The images or other third party material in this article are included in the article's Creative Commons licence, unless indicated otherwise in a credit line to the material. If material is not included in the article's Creative Commons licence and your intended use is not permitted by statutory regulation or exceeds the permitted use, you will need to obtain permission directly from the copyright holder. To view a copy of this licence, visit http://creativecommons.org/licenses/by/4.0/. The Creative Commons Public Domain Dedication waiver (http://creativecommons.org/publicdomain/zero/1.0/) applies to the data made available in this article, unless otherwise stated in a credit line to the data. 
large areas of its agricultural lands, in addition to the growth of informal settlements with poor living conditions. The city suffers many problems, like traffic congestion, poor air quality, water pollution and inefficient waste management [7, 22, 27]. Along with these problems, Cairo also lacks the presence of sufficient green spaces that can mitigate these problems and decrease their harmful effects.

This article assesses the current situation regarding the provision of green spaces and public parks in Cairo. The goal is to highlight the critical position the city is currently at regarding the presence of sufficient quantities and adequate distribution of green spaces by providing recent numerical data that overcome the limitation in the currently available sources. The "Methods" section explains the scope of the study, the types of green spaces included and the process of data acquisition. Types of green spaces the study includes are amenity green spaces between residential blocks, street green spaces, plant nurseries under public management and public parks. It also focuses only on green spaces and public parks in Cairo's districts and does not include new communities.

Afterwards, the results compare the most recent changes, during the years 2017 and 2020, in the provision of green spaces in Cairo as a whole and in its districts. They also show the existing public parks in the city, their areas and distribution. Finally, the discussion follows the green spaces changes that happened over the years, extending to the years 2000 and 2006, reaching the current critical state of low presence and poor distribution of green spaces over the city. The trend of disappearing green spaces is discussed within the urban development approach that has been followed recently in Cairo. The negative effects of losing green spaces in Cairo are also highlighted. The discussion also examines the problems related to the lack and fragmentation of Cairo's green spaces data.

\section{Methods}

\section{Research scope: Green spaces in Cairo}

Cairo City is divided into 4 main regions (Southern, Western, Northern and Eastern) which consist of 37 districts. At the periphery of the southern and eastern regions, there are 4 new communities. The districts and new communities lie under different administrative jurisdictions, but together they form the boundaries of Cairo Governorate. This research focuses on public green spaces in the 37 districts of Cairo City (Fig. 1).

Urban green spaces are vegetated open spaces in cities that can be either public or private $([15,26]$, p. 282 and 778 [16, 18];). Cairo has several types of public green spaces that differ in areas, features and use. The city does not have an official classification for all its green areas except for the classification adopted by Cairo Cleanliness and Beautification Agency (CCBA) which covers only the green spaces they manage. According to CCBA data, the agency divides green spaces into six categories: 1) public parks, 2) main axes green spaces, 3) self-efforts green spaces, 4) nurseries, 5) Distinctive Gardens (DG) and 6) Specialised Gardens (SG) (Table 1).

Green spaces categories adopted by CCBA are different from the common categories found in literature. For example, as the main feature of CCBA public parks, is being free, green space in a residential block or a green strip along a street are included. They do not separate between amenity green spaces and linear green spaces along streets 


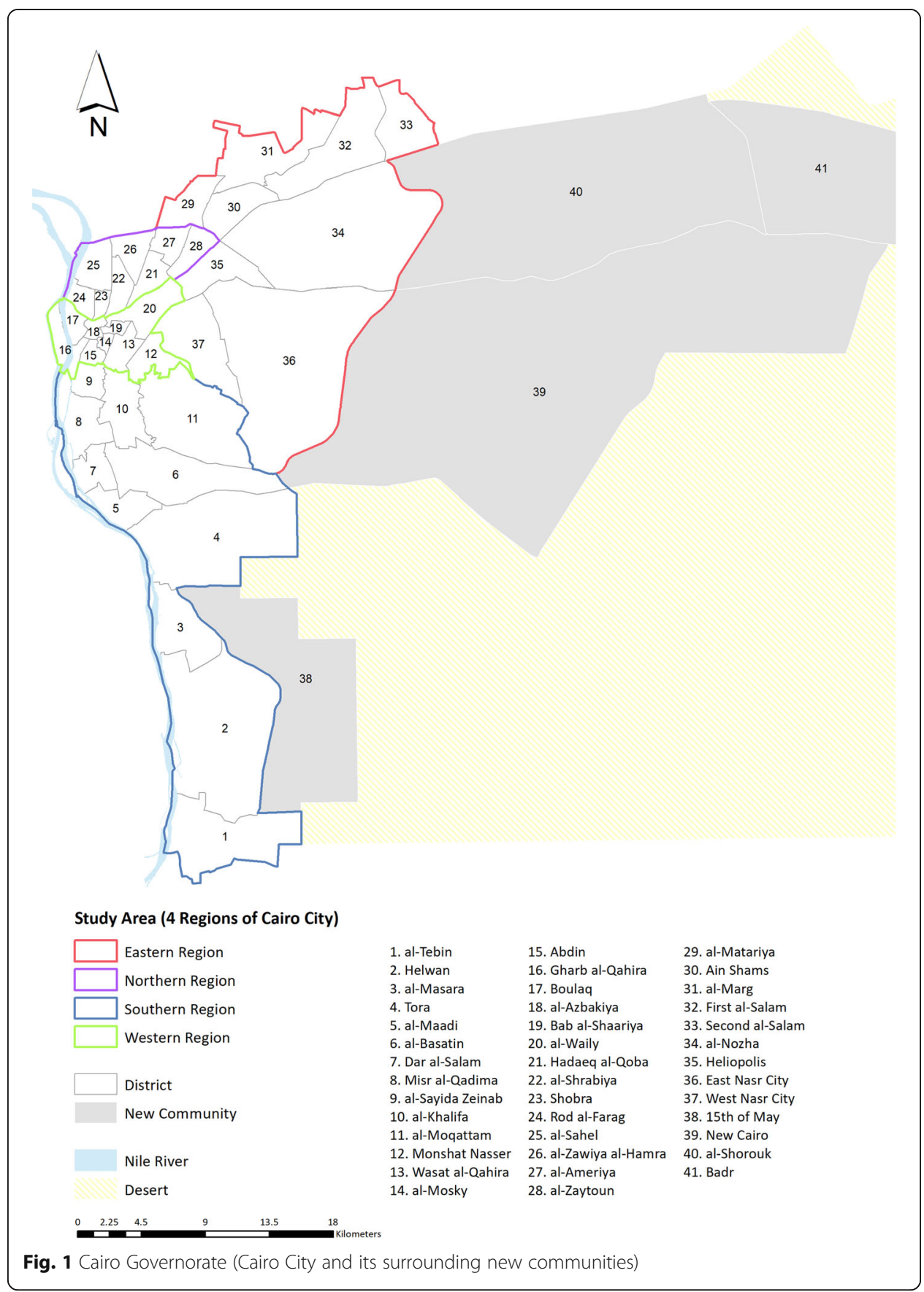

except for major streets. DG and SG are the public parks in Cairo as they are green spaces used mainly for recreation [26]. However, they do not have free access and CCBA does not categorise them as public parks. Public parks, including DG, SG and other major public parks in Cairo, are one of the green space types that are included within this study in more detail.

Cairo also has other types of public and private green spaces. For example, private clubs and youth clubs often include some green areas. Institutional buildings like schools, universities, museums and other public buildings may also have green areas. These types of green spaces can contribute to providing several benefits to the city, but 
Table 1 CCBA Categorisation for green spaces and equivalent category in literature

\begin{tabular}{|c|c|c|}
\hline CCBA category & Definition & $\begin{array}{l}\text { Categories according } \\
\text { to Swanwick et al. [26] }\end{array}$ \\
\hline \multirow[t]{2}{*}{ Public parks } & \multirow[t]{2}{*}{$\begin{array}{l}\text { Amenity green spaces in the districts' streets, squares and } \\
\text { between buildings in residential areas that are free to use }\end{array}$} & $\begin{array}{l}\text { Amenity/incidental } \\
\text { green spaces }\end{array}$ \\
\hline & & Linear green spaces \\
\hline Main axes green spaces & Green spaces at the middle or sides of main streets & Linear green spaces \\
\hline Self-efforts green spaces & $\begin{array}{l}\text { Green spaces created through collective efforts of residents } \\
\text { and the support of CCBA }\end{array}$ & $\begin{array}{l}\text { Amenity/incidental } \\
\text { green spaces }\end{array}$ \\
\hline Nurseries & $\begin{array}{l}\text { Used to grow different types of vegetation to be used by } \\
\text { CCBA and to sell to the public }\end{array}$ & Functional green spaces \\
\hline Distinctive gardens (DG) & $\begin{array}{l}\text { Green spaces that are controlled and actively managed } \\
\text { for recreational use by a dedicated management agency- } \\
\text { the DG Administration }\end{array}$ & $\begin{array}{l}\text { Amenity/recreational } \\
\text { public park }\end{array}$ \\
\hline Specialised gardens (SG) & $\begin{array}{l}\text { Green spaces that are controlled and actively managed for } \\
\text { recreational use by a dedicated, independent management } \\
\text { agency - the SG Administration }\end{array}$ & $\begin{array}{l}\text { Amenity/recreational } \\
\text { public park }\end{array}$ \\
\hline
\end{tabular}

they have not been included in this study for two reasons: the limited public accessibility of some of these green spaces and the lack of comprehensive data that covers all of them as the responsibility of their management is divided between several authorities. Accordingly, this research covers only standalone types of green spaces and those that are part of a street or a square.

\section{Data acquisition}

To analyse the current situation in Cairo regarding its green spaces, three data types were required: (1) areas of green spaces in different districts, (2) population number at each of them and (3) shapefile for the administrative boundaries of Cairo and the division of its districts. The shapefile was acquired from the "Transport for Egypt Project" and modified to be integrated with the other data types. Population data and green spaces areas for 2020 were linked geographically in ArcMap with the shapefiles of the districts to create a database for green spaces in Cairo. They were used to calculate the 2020 individual share of green spaces in Cairo and in each of its districts which were also added to the database. Finally, points were created for public parks locations in Cairo. The data were used to create maps using ArcMap, besides representing them in tables and graphs. Detailed tables and additional information about data acquisition are included as Supplementary materials.

For population data, the research depended on the data published by the CAMPAS [12] for the year 2017, and for 2020, the Cairo Governorate Portal [10] was used. On the other hand, finding accurate data about areas of green spaces in Cairo can be difficult. The data available from previous research are outdated and GIS mapping for green spaces in Cairo is not available online. To achieve comprehensive data within the current limited availability, the research synthesised areas of green spaces from various sources for the years 2017 and 2020.

First of all, because CCBA manages most of the City's green spaces, the agency was contacted to provide the data for the green spaces' areas. Excel files were obtained with areas of green spaces in each district in Cairo for the years 2017 and 2020. These data covered the types of green space that were presented in Table 1 except for the SG. 
Secondly, other agencies were contacted for some missing data for the similar types of green spaces: (1) the SG Administration: for the SG areas, and (2) al-Nasr Company: for additional residential amenity/incidental green spaces that they still manage and are not handed over to CCBA in two districts, al-Moqattam and al-Basatin. Finally, areas of well-known public parks, which are not managed by either CCBA or the SG Administration, were also added from internet sources or calculated using ArcMap. These major parks included: the Cultural Park for Children (CPC) [1], al-Fustat Park ${ }^{1}$ and Arab al-Mohamady Park ${ }^{2}$ [5] (which are managed by CCBA and were yet not included in their data), al-Azhar park [2], Merryland Park [14], al-Zohriya Park (Cairo [9]), the Aquarium Grotto Park [25], the Child Centre of Civilization and Creativity (CCCC), alMaadi Island, al-Helmiya, Badr, al-Andalusiya and Panorama October parks ${ }^{3}$.

\section{Modified data from previous research}

The most recent data that were mentioned in the previous part needed to be compared in the discussion with data from previous years to show the changes that happened in Cairo. Data were found for the years 2000 and 2006 from previous research. However, these data could not have been discussed directly and some modifications were required to allow more consistency in the comparison. The boundaries of Cairo for all the years are the same but the internal divisions of the districts have some changes. Some districts that were previously merged and managed as one, have been divided into two separate districts. Besides presenting the data according to the most recent divisions, green spaces areas, population number and the individual share of green spaces were recalculated for the merged districts to allow a consistent comparison between the 4 years.

For the year 2006, a master thesis by Assem Shaban ${ }^{4}$ (2009) included a study of green spaces' areas in Cairo. His research also depended on data from CCBA. The excel file Shaban originally acquired was requested, and he sent it by email. The table in the excel file included areas for green spaces in each district in Cairo divided into CCBA categories but including also youth centres and sports clubs, and green spaces inside governmental buildings. A sum was calculated for each district to be used in this research but excluding youth centres and sports clubs, and green spaces inside governmental buildings as these types are not within the scope of this research as mentioned earlier. Population data for the year 2006 were available from CAPMAS [13].

For the year 2000, al-Zafarany [4] article was used as a source for data but some modifications were needed also for consistency. The article categorised green spaces as recreational areas which indicated that the total areas might not include only green spaces. That was confirmed when the data were revised in detail and green spaces' areas in some districts were shown to have a high value when compared to the year

\footnotetext{
${ }^{1}$ Area was calculated using ArcMap because official sources mention a much bigger area for the park which by examining the satellite images and after visiting the park was found to be significantly less than that mentioned area.

${ }^{2}$ At the beginning of 2021, Arab al-Mohamdy park and the SG, al-Waily, were handed over to Ain Shams University after an administrative decision that the two parks belong to the Faculty of Medicine Campus. ${ }^{3}$ Areas were calculated using ArcMap because there were not any data available online for the areas of these parks.

${ }^{4}$ The data in his thesis included a different boundary for Cairo with fewer districts which would have made any comparison inaccurate, so it was better to get the original data and recalculate the values to unify the boundaries and the number of districts.
} 
2006. Al-Zafarany data were also originally from CCBA which is expected to have the same format as the data from the year 2006. It was concluded that youth centres and sports clubs were part of the recreational areas he calculated. Accordingly, the youth centres and sports clubs areas in the 2006 data were subtracted from the totals of each district mentioned by al-Zafarany [4]. The establishment dates of the youth centres and sports clubs were revised using the Ministry of Youth and Sports website to ensure that there were not any new centres or clubs between the two dates. The population data used by al-Zafarany were used after correcting a minor mistake in the population number of al-Moqattam and al-Khalifa districts.

\section{Results}

\section{Green spaces provision and distribution in Cairo}

Figure 2 shows the dominance of desert areas, the dense urban fabric and the low availability of green spaces in Cairo. The data collected about green spaces in Cairo shows that the city has a limited presence of green spaces. Between the years 2017 and 2020, Cairo lost $910,894 \mathrm{~m}^{2}$ of its already limited green spaces. With the increase of its population number, the individual share of green spaces decreased from 0.87 to $0.74 \mathrm{~m}^{2}$ (Table 2). The highest loss of green spaces was mainly in Heliopolis and East Nasr City. Heliopolis lost 272,274 $\mathrm{m}^{2}$ between the years 2017 and 2020 while East Nasr City lost $311,283 \mathrm{~m}^{2} 5$.

Moreover, Cairo does not only have a problem with the overall quantity of green spaces but also with their uneven distribution across its districts ${ }^{6}$ (Figs. 2, 3 and 4). In the year 2020, 22 districts out of 37 , where $66 \%$ of the population live, had an individual share of green spaces less than $0.50 \mathrm{~m}^{2}$. The lowest share in this category is $0.01 \mathrm{~m}^{2}$ at al-Matariya and the highest is at Abdin, $0.46 \mathrm{~m}^{2}$. Only 5 districts have an individual share of more than $3 \mathrm{~m}^{2}$ : Gharb al-Qahira $\left(10.04 \mathrm{~m}^{2}\right)$, al-Maadi $\left(5.27 \mathrm{~m}^{2}\right)$, al-Nozha $\left(5.00 \mathrm{~m}^{2}\right)$ and Heliopolis $\left(3.52 \mathrm{~m}^{2}\right)$. Wasat al-Qahira district is the location of al-Azhar park and also has a relatively low population number which contributed to its placement amongst the higher categories of individual share of green spaces in Cairo with $3.22 \mathrm{~m}^{2} /$ individual.

Finally, 7 districts in Cairo lie between 0.50 and $1.50 \mathrm{~m}^{2}$ of green spaces per individual. This means that $83 \%$ of Cairo's population live in districts with an individual share of green spaces less than $1.5 \mathrm{~m}^{2}$. Al-Basatin is the lowest in this category with $0.54 \mathrm{~m}^{2}$ / individual and Misr al-Qadima is the highest with $1.35 \mathrm{~m}^{2}$ /individual. The individual shares for the other five districts are al-Azbakiya $\left(0.59 \mathrm{~m}^{2}\right)$, al-Mosky $\left(0.90 \mathrm{~m}^{2}\right)$, Helwan $\left(0.91 \mathrm{~m}^{2}\right)$, al-Tebin $\left(1.13 \mathrm{~m}^{2}\right)$ and al-Waily $\left(1.19 \mathrm{~m}^{2}\right)$. The middle category, between 1.50 and $3.00 \mathrm{~m}^{2}$ of green spaces per individual, has only 3 districts: East Nasr City (1.69 $\mathrm{m}^{2}$ /individual), al-Moqattam $\left(1.80 \mathrm{~m}^{2}\right.$ /individual $)$ and West Nasr City $\left(2.86 \mathrm{~m}^{2} /\right.$ individual). East Nasr City, despite having the second-highest green spaces area in Cairo $\left(1,116,468 \mathrm{~m}^{2}\right)$, its high population number lowered the residents' share of green spaces significantly.

\footnotetext{
${ }^{5}$ For the detailed data of green spaces in Cairo, check Tables 1 and 2 in the Supplementary materials. ${ }^{6}$ For the detailed data of green spaces distribution in Cairo, check Tables 1 and 2 in the Supplementary materials.
} 


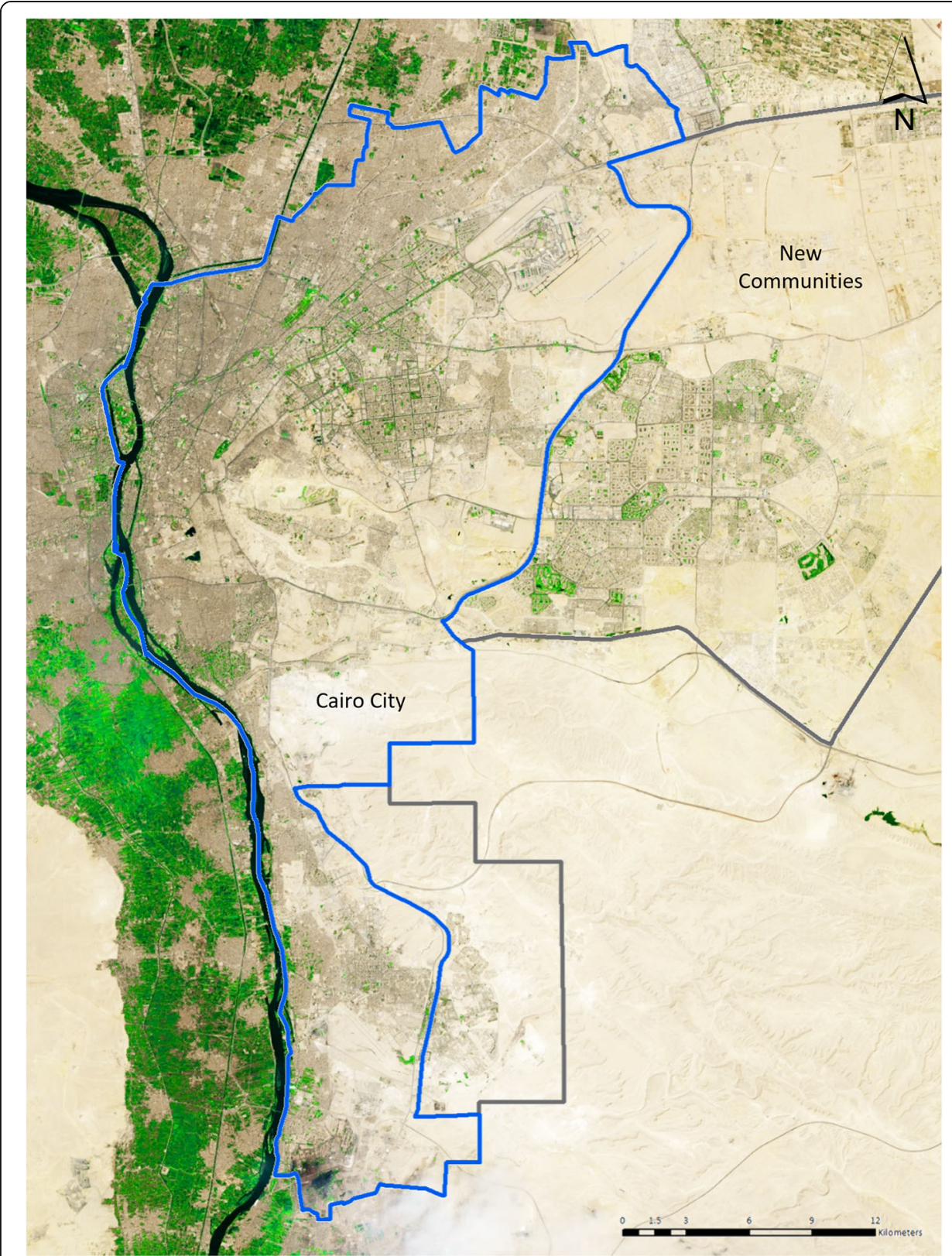

Fig. 2 Satellite image taken in September 2019 showing green spaces in Cairo. Intensity of the green colour was changed to show the green spaces more clearly. Original satellite image is from Nasa Earth Observartory—https://earthobservatory.nasa.gov/images/146

\section{Public park provision, distribution and area categories in Cairo}

Fifty-four public parks have been identified in Cairo that have dedicated management and offer active recreation ${ }^{7}$. The distribution of these parks is not equal between Cairo's districts (Fig. 5). Many districts that do not have green spaces in general also do not have public parks, while some of them have more of the other types of amenity green spaces and private clubs but fewer public parks. Al-Nozha District, for example, has one of the highest quantities of green spaces in Cairo, but it only has the Child

${ }^{7}$ For the detailed data of public parks in Cairo, check Table 3 in the Supplementary materials. 
Table 2 Summary of green spaces data in the years 2017 and 2020

\begin{tabular}{llll}
\hline Year & Green spaces area $\mathbf{m}^{\mathbf{2}}$ & Population number & Individual share of green spaces $\mathbf{~}^{\mathbf{2}}$ /individual \\
\hline 2017 & $7,834,388$ & $9,030,128$ & 0.87 \\
2020 & $6,923,494$ & $9,415,766$ & 0.74 \\
\hline
\end{tabular}

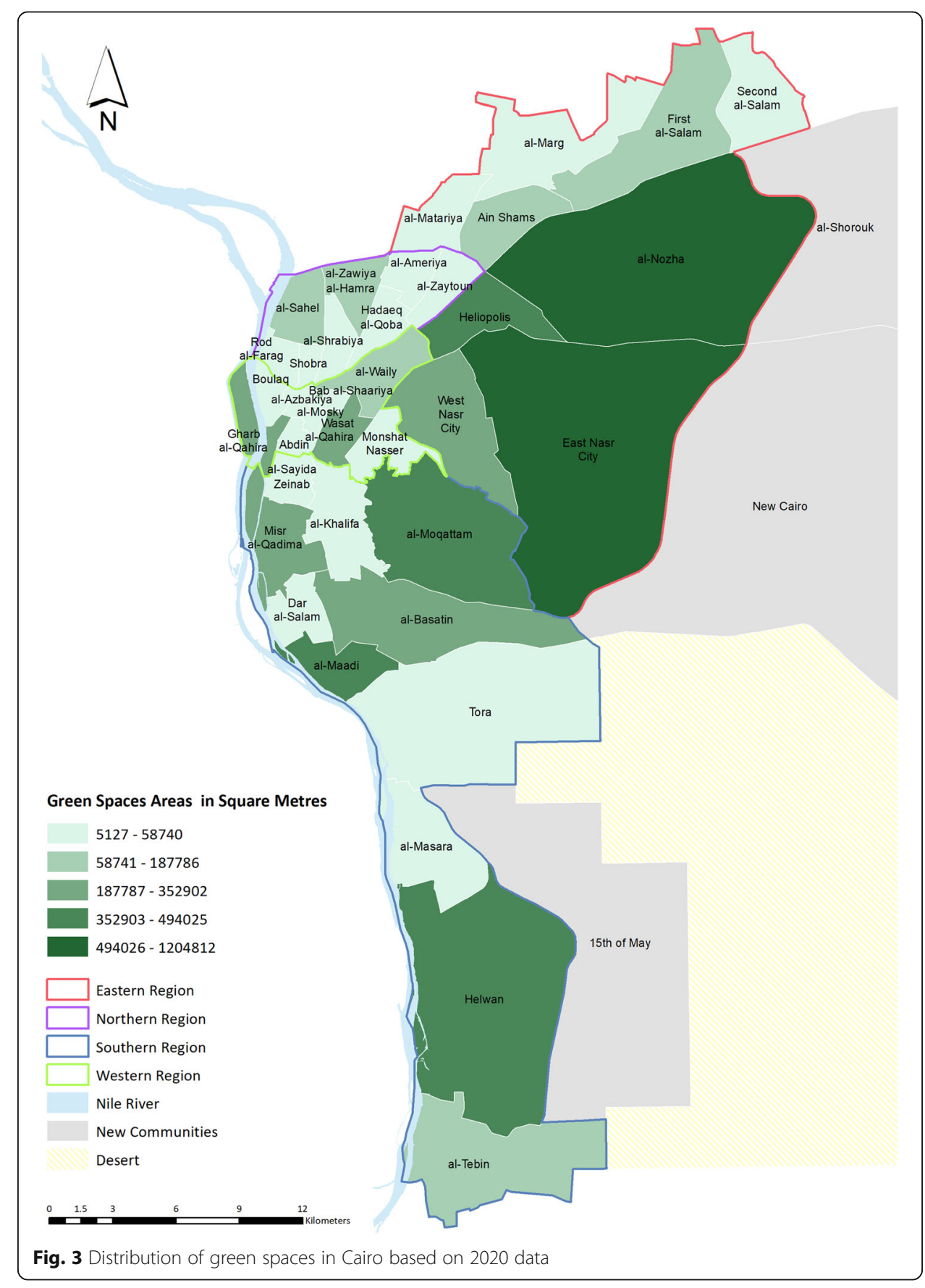




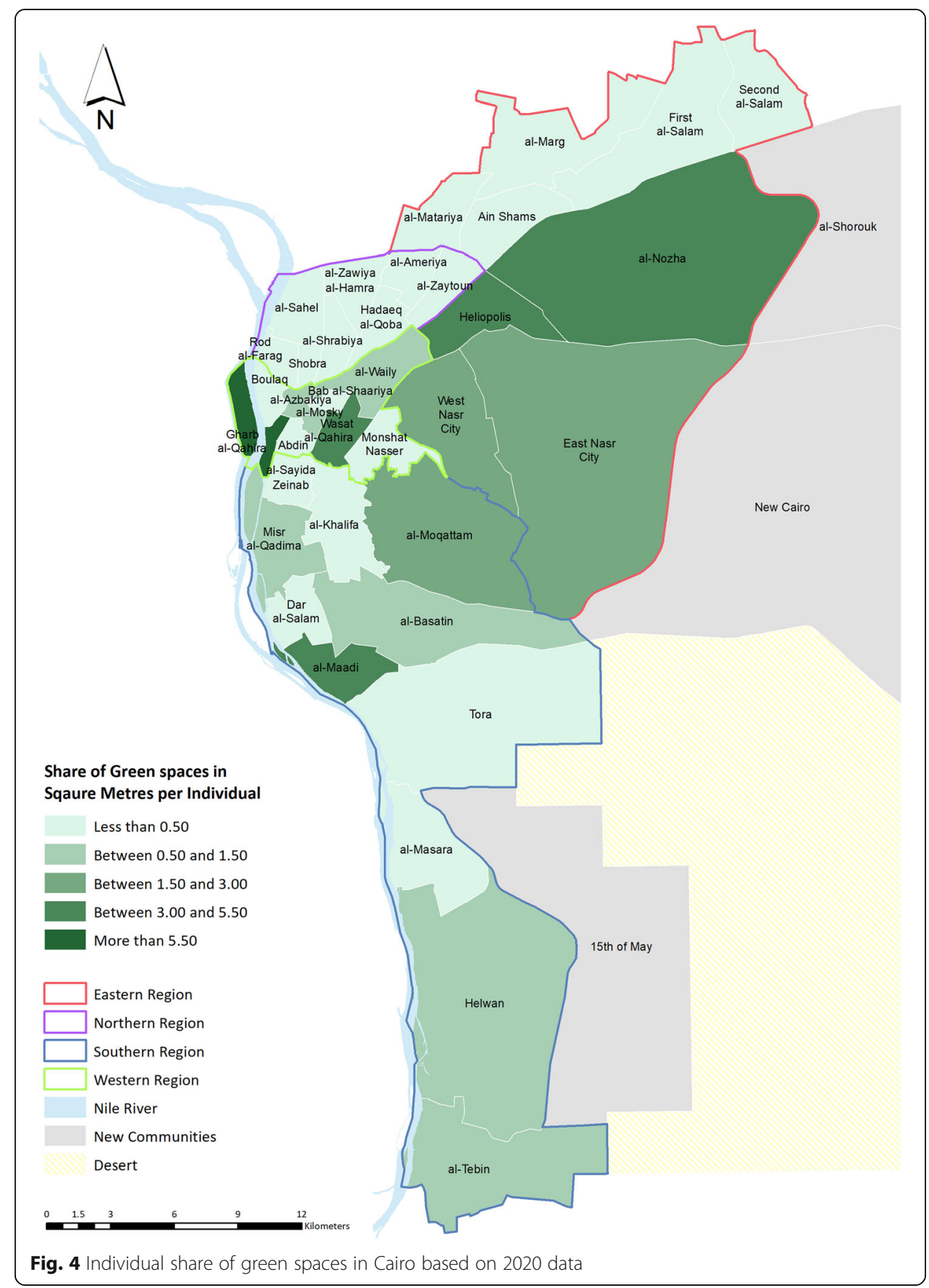

Centre of Civilization and Creativity (CCCC) which is partially a park but mainly a museum for children. Similarly, Heliopolis only has Merryland Park which is currently closed.

Gharb al-Qahira has the highest number of public parks and also the highest individual share of green spaces in Cairo. It has 8 parks, 7 of which are at al-Zamalek Island. In general, most of Cairo's public parks are divided between its southern and eastern regions with 18 and 16 parks respectively. However, 5 out of 11 districts in the southern region and 3 districts out of the 9 districts of the eastern region do not have any 


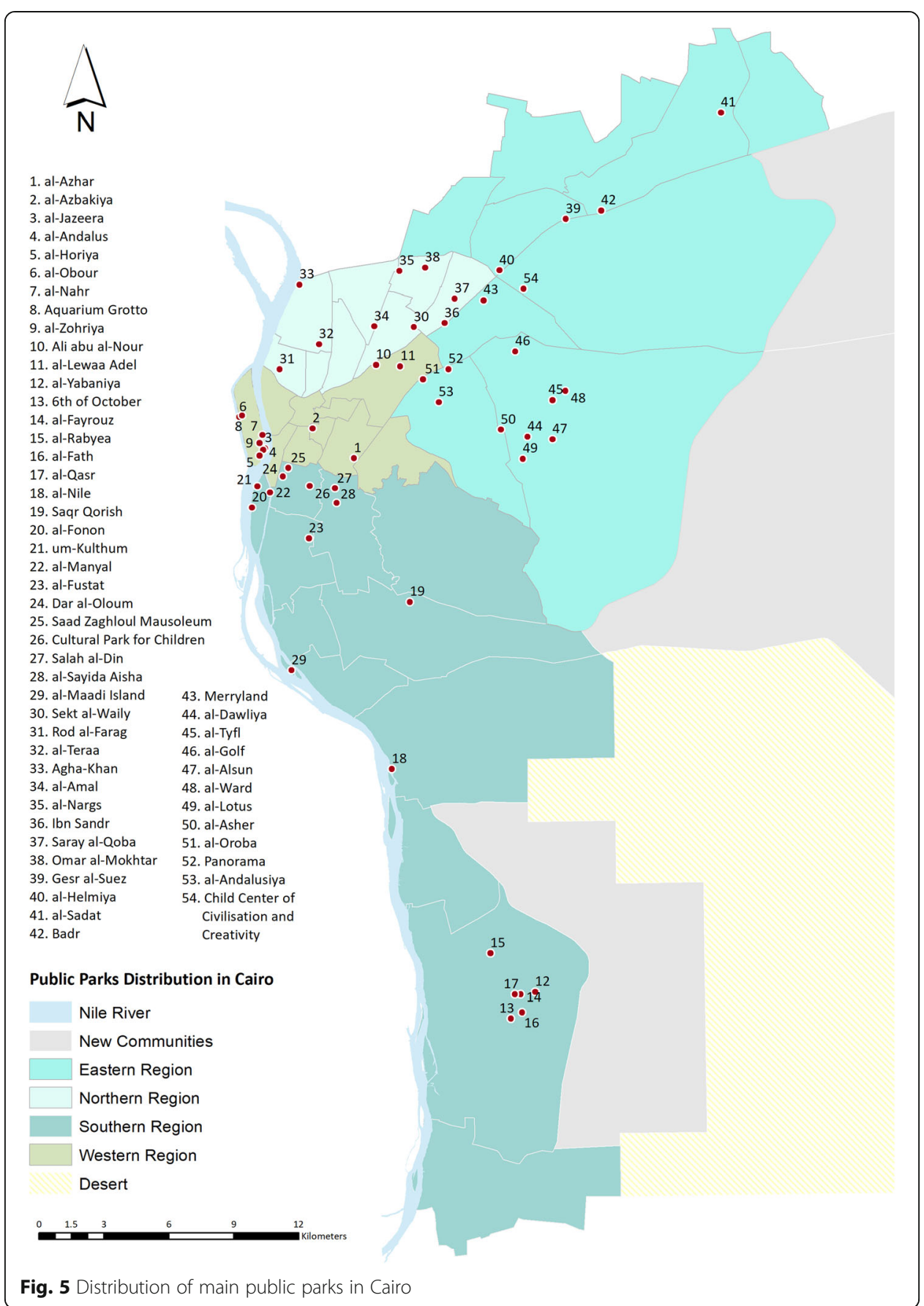

public parks. Districts like al-Matariya, al-Marg, Dar al-Salam, Tora and Monshat Nasr that have close to zero green spaces do not have any public parks either.

According to Swanwick et al.'s [26] hierarchy of public parks ${ }^{8}$ (Fig. 6), most public parks in Cairo, 20 out of 54, have an area between 12,000 and 40,000 $\mathrm{m}^{2}$. The second-

${ }^{8}$ For the detailed data of the categories of public parks in Cairo, check Table 4 in the Supplementary materials. 


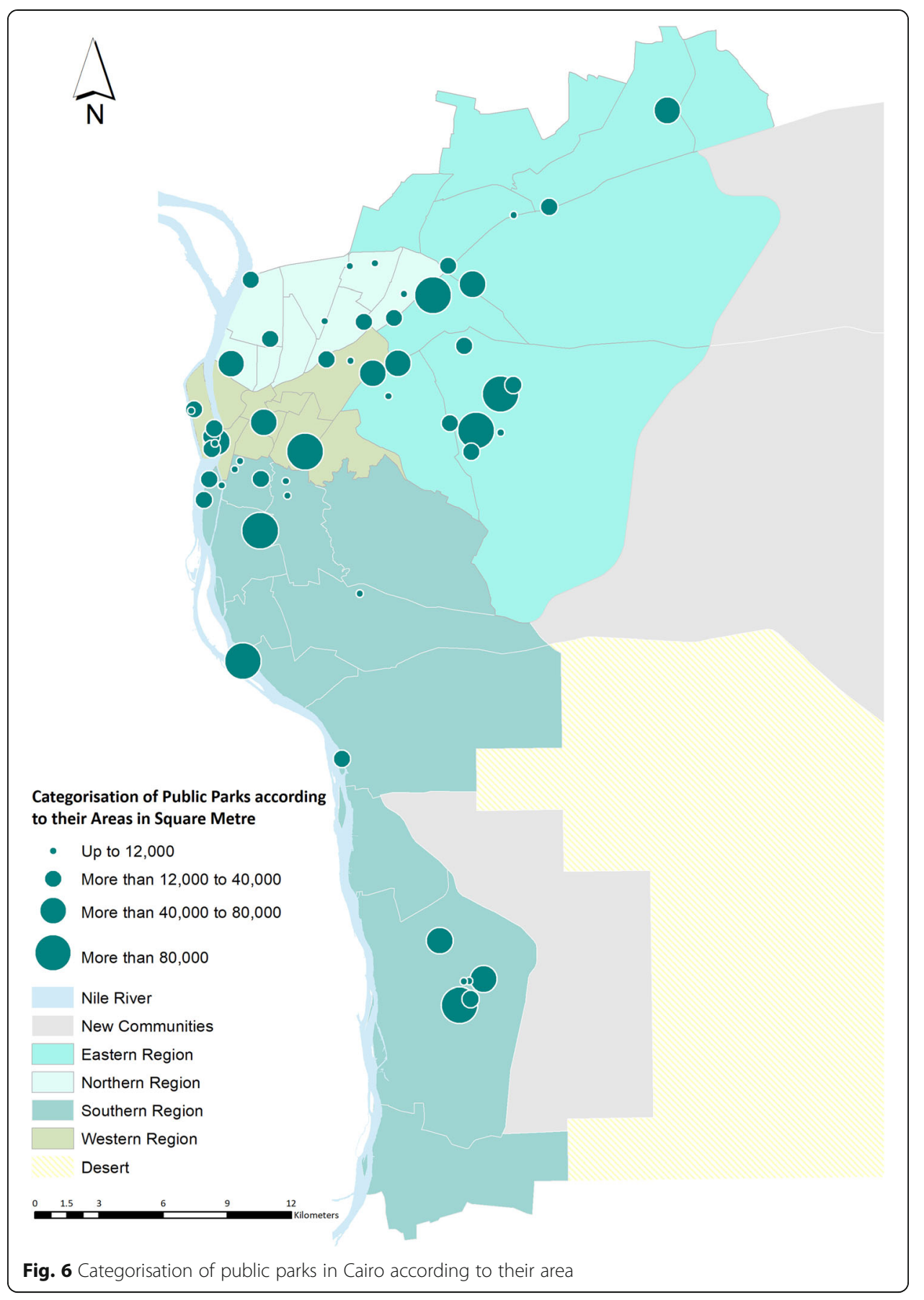

highest category in the number of public parks has parks even smaller in area (less than or equal to $12,000 \mathrm{~m}^{2}$ ). 18 parks lie in this category, including a park as small as 2000 $\mathrm{m}^{2}$. In general, Cairo has few large parks, 7 with an area larger than $80,000 \mathrm{~m}^{2}$ and 9 between 40,000 and $80,000 \mathrm{~m}^{2}$. The largest parks in Cairo are the $300,000 \mathrm{~m}^{2}$ al-Azhar park, al-Dawilya Park and the currently closed Merryland Park which both have an area of $210,000 \mathrm{~m}^{2}$. 


\section{Discussion}

\section{Continuous loss of green spaces in Cairo}

Based on the data published by al-Zafarany [4], the calculated individual share of green spaces for the year 2000 was $0.98 \mathrm{~m}^{2} /$ individual. This is different from what he mentioned in his article as he estimated the individual share to be $1.5 \mathrm{~m}^{2}$ /individual. His estimation is higher because he included youth centres, sports clubs and added part of the Nile surface. In 2005 al-Azhar park was established at Wasat al-Qahira District and added a significant area of $300,000 \mathrm{~m}^{2}$ to the green spaces of the city. This contributed to slightly enhancing the individual share of green spaces. In 2006, the individual share of green spaces increased to $1.18 \mathrm{~m}^{2} /$ individual. It decreased in 2017 to be $0.87 \mathrm{~m}^{2}$ and continued to decrease to reach $0.74 \mathrm{~m}^{2} /$ individual in 2020 . By the year 2020, Cairo has lost 2,128,280 $\mathrm{m}^{2}$ of green spaces compared to 2006. $910,894 \mathrm{~m}^{2}$ were lost in the three years between 2017 and 2020 .

Cairo kept losing green spaces without any major new additions. The resultant overall trend is a decrease in the total area of green spaces and an increase in population number which together led to the decrease in the individual share of green spaces (Fig. 7). Over the years and even in the highest recorded estimations, Cairo has always had an individual share of green spaces far less than the international recommended standards, for example, $9 \mathrm{~m}^{2} /$ individual as suggested by the World Health Organization [21]. It is even less than the minimum local standards for existing cities as suggested by the National Organization for Urban Harmony (NOUH) which are $7 \mathrm{~m}^{2}$ /individual and $5 \mathrm{~m}^{2} /$ individual for the Nile Valley cities and desert cities respectively $[28]^{9}$.

Also, disparities between districts did not change over the years showing that no efforts or interventions were made to enhance the situation. Districts with the lowest and highest individual share of green spaces remained almost the same. However, some districts with the highest individual share lost a significant amount of their green spaces. For example, Misr al-Qadima had a slight increase in its residents' share in 2006 (3.32 $\mathrm{m}^{2}$ ) and decreased again below its value in $2000\left(2.77 \mathrm{~m}^{2}\right)$ to reach $1.72 \mathrm{~m}^{2}$ in 2017 and $1.35 \mathrm{~m}^{2}$ in 2020. Wasat al-Qahira, on the other hand, witnessed a major transformation in the year 2006 because of the establishment of al-Azhar Park. The individual share of green spaces increased from $0.23 \mathrm{~m}^{2}$ in 2000 to $3.09 \mathrm{~m}^{2}$ in 2006. It slightly increased again in 2017 to reach $3.37 \mathrm{~m}^{2}$ and fall to $3.22 \mathrm{~m}^{2}$ in 2020 .

In Heliopolis, the individual share of green spaces dropped from its highest in 2006 $\left(6.38 \mathrm{~m}^{2}\right)$ to $3.52 \mathrm{~m}^{2}$ in 2020 . Heliopolis Heritage Initiative documented the loss of green spaces with an estimation of $390,000 \mathrm{~m}^{2}$ of lost green spaces between different streets and squares in the district [19]. Official data from CCBA shows a different value for lost green spaces, 272,274 $\mathrm{m}^{2}$ between the years 2017 and 2020, which is still a significant loss that contributed to the individual share of green spaces losing around twofifths of its value. East Nasr City also had its highest individual share in $2006\left(4.89 \mathrm{~m}^{2}\right)$ which declined in 2020 to be $1.69 \mathrm{~m}^{2}$. East Nasr City also lost $311,283 \mathrm{~m}^{2}$ of its green spaces between 2017 and 2020 lowering the individual share of green spaces by $25 \%$.

Unequal distribution is found in public parks too despite reopening some closed CCBA green spaces to be used as public parks (the DG category which added 16 public

${ }^{9}$ The NOUH standards are for open spaces not only green spaces which can include sports and youth clubs and schools, etc. However, to fulfil the standards, their areas should not count for more than half the total area calculated for open spaces. Private gardens and open spaces cannot be included. 


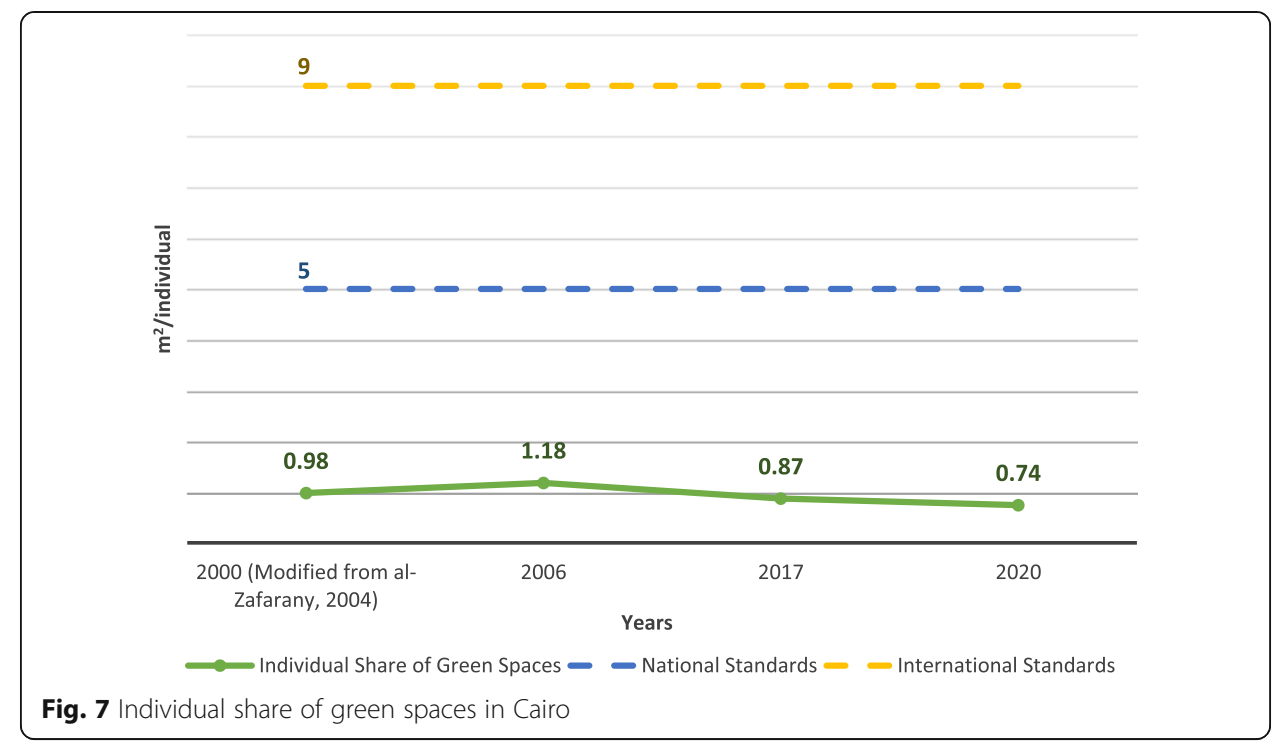

parks to Cairo over the years). The standards published by the NOUH mention that each district should have a district park of at least $21,000 \mathrm{~m}^{2}$ and that each resident should access a public green space of at least 12,600 $\mathrm{m}^{2}$ within $1 \mathrm{~km}$ from their homes. The uneven distribution of green spaces and public parks around the city does not allow such access for most of Cairo's residents. Also, 16 districts out of 37 in Cairo have no public parks and the area of 27 out of 54 its parks is less than 21,000 $\mathrm{m}^{2}$.

Despite the obvious lack of green spaces in Cairo, the existing ones with their limited areas are often under threat. That is because green spaces have always been the first victim of urbanisation and infrastructure projects. Projects to widen roads or build vehicle bridges are given priority over protecting green spaces. Examples of these projects were the construction of the 6th of October bridge, al-Azhar tunnel and widening of Ramses Street. Also, green spaces can often be sacrificed easily to build new service and administrative buildings like the loss in areas in al-Azbakiya, and al-Zohryia Parks [3, 5], and other green spaces in Cairo (Fig. 8). Giving priority to other projects over green spaces indicates a lack of awareness of their importance and the harmful impact that would result from removing them. More recently, this practice has continued and major road infrastructure projects have been established in Cairo destroying many of its green spaces especially in Heliopolis and Nasr City as mentioned earlier (Figs. 9, 10 and 11).

Losing green spaces can have major harmful effects on any district and the wellbeing of its residents. A general decline in the quality of life in Heliopolis district, for example, was reported due to the loss of green spaces. Environmental and visual quality has declined which is worsened by bridges always interrupting visual continuity, the quality of sidewalks has decreased and crossing the roads for pedestrians became less safe [8]. A significant increase in traffic accidents was recorded shortly after those developments. Sidewalks also lost shade which is an important factor for walkability due to the cutting and uprooting of trees [6].

Infrastructure projects currently dominate the scene in Cairo and keep finding their way to more of its districts. New projects have been recently announced at al-Nozha and al-Maadi districts that are expected to change the fabric of another two districts 


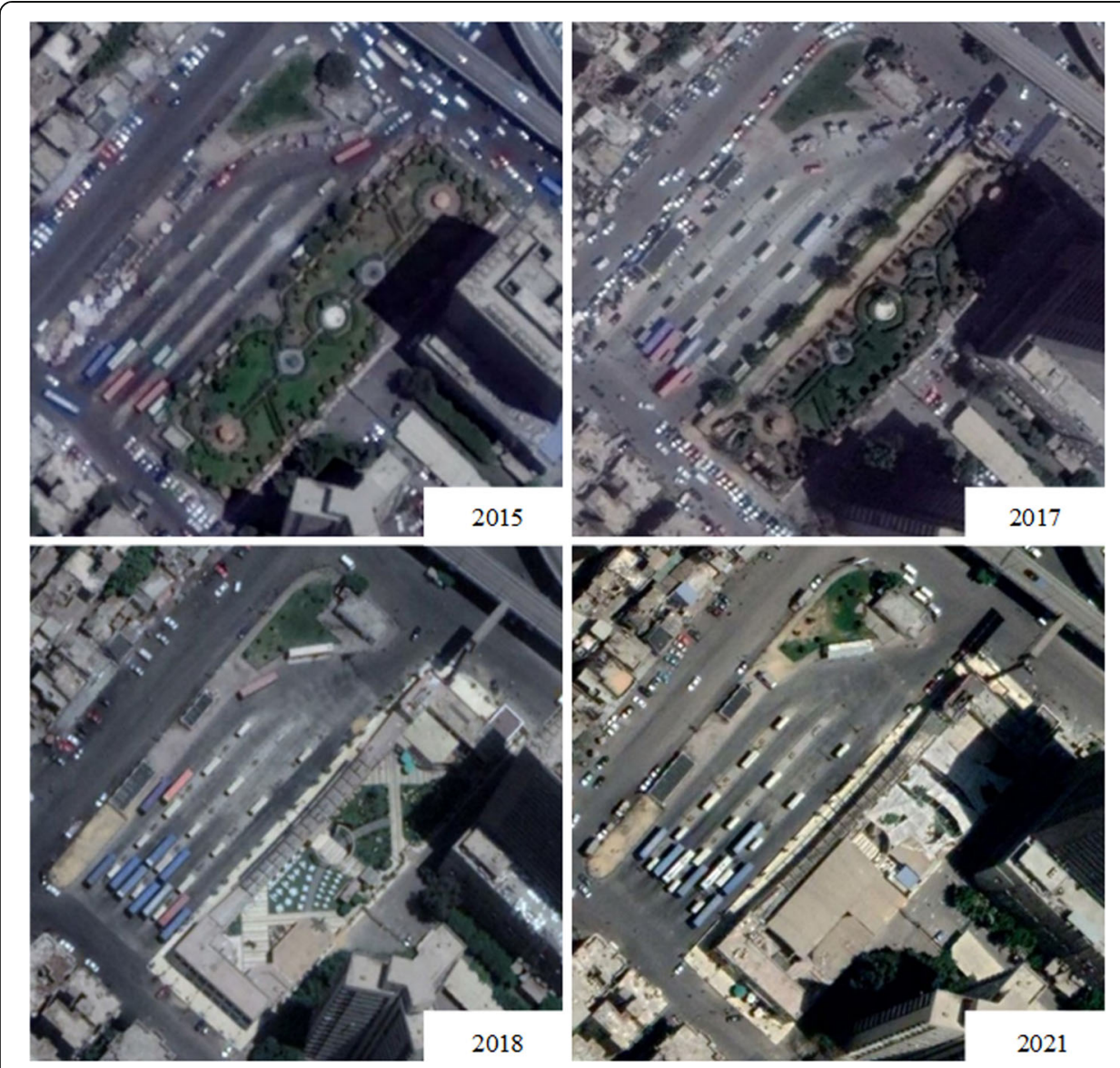

Fig. 8 Change in a green space at al-Abbasiya Square, al-Waily District, Map data @ 2021 Google

known for their green spaces. Social media users frequently document the actual or intentional destruction of green spaces and the cutting of trees in different streets in Cairo. Recent images showed, for example, partial demolitions and construction work being carried out at several parks and nurseries. The final status of these interventions is still not known but if they went through, Cairo would lose at least an additional $124,236 \mathrm{~m}^{2}: 91,920 \mathrm{~m}^{2}$ at al-Waily district alone (around half the district's green spaces and total area of Arab al-Mohamdy and al-Waily parks that were handed over from CCBA to Ain Shams University to be part of its Faculty of Medicine campus), additional 23,100 $\mathrm{m}^{2}$ at Heliopolis (area of Heliopolis CCBA Nursery) and 9,216 $\mathrm{m}^{2}$ at Ain Shams (area of Gesr al-Suez Park and one of only two public parks in the district). This is in addition to other green spaces and trees that are expected to be lost at al-Maadi and al-Nozha.

Green spaces and public parks under governmental management also suffer from serious deterioration in quality and heavy commercialisation. Cairenes' access to green spaces and public parks keeps diminishing with the increase in the cost of using public parks (rise in ticket prices and additional costs for activities inside most parks) and the closure of other amenity green spaces and public parks (Figs. 12 and 13). Green spaces are often closed to protect them from being heavily used. Responsible administrations claim that people's behaviour in green spaces will make them deteriorate rapidly and 

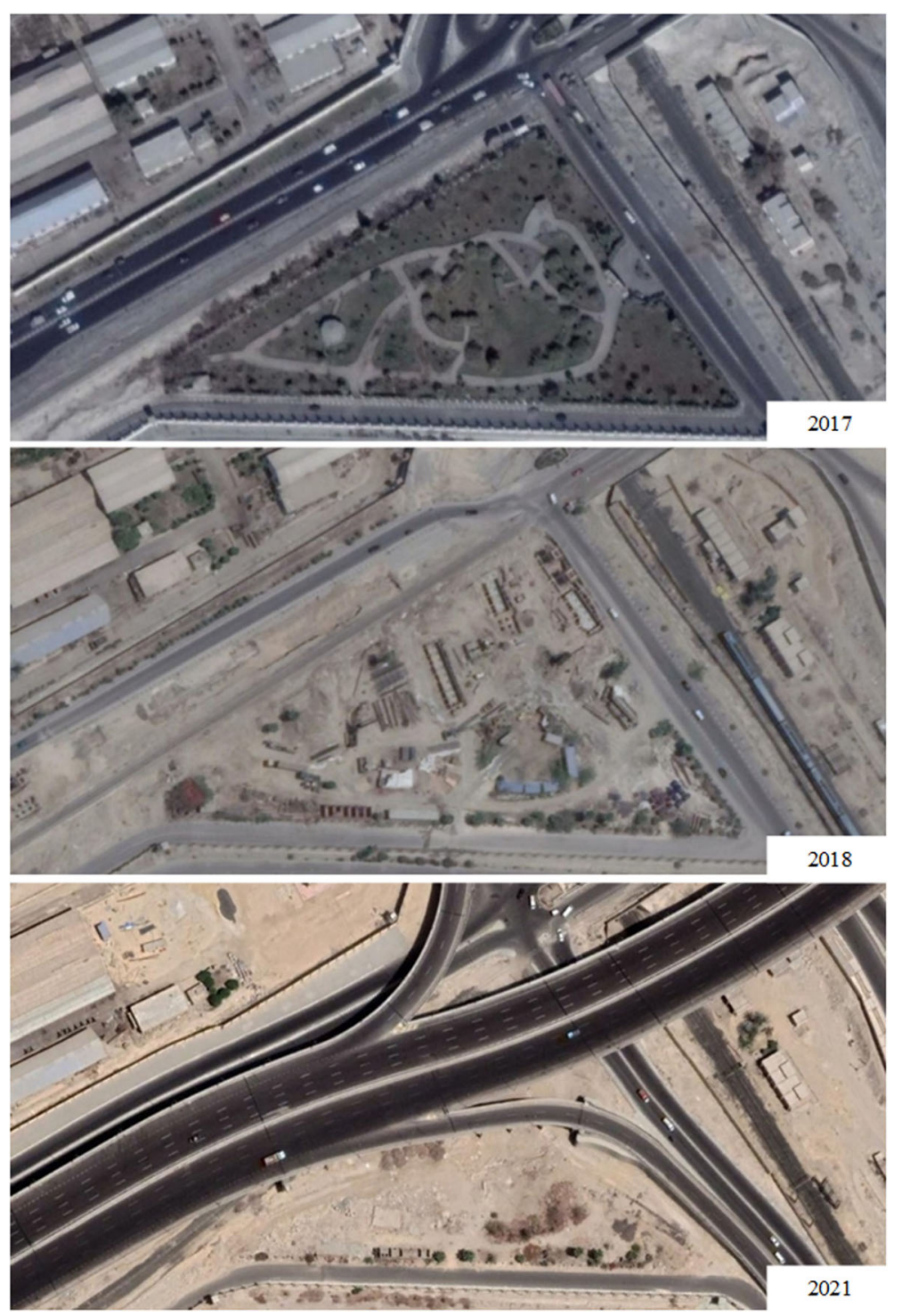

Fig. 9 al-Mostaqbl Park, Helwan District, Map data @ 2021 Google

that they do not have sufficient resources to mitigate the damage. In fact, most of these closed green spaces end up in worse conditions. Public parks that do not bring reasonable revenue or in districts where residents are known to cause some problems when using the parks are sometimes decided to be closed or end up being neglected.

Moreover, many of Cairo's public parks were managed originally with a minimum entrance fee to allow lower-income groups to use them. However, prices kept being raised because of the economic and social shifts in Egypt and the significant increase in services costs in general. According to al-Messiri [3], in 2004, most SG tickets were 1 Egyptian Pound. Seven out of the 23 SG at the time had a ticket half this value because they were located in lower-income districts. The Aquarium Grotto and al-Fustat Park tickets were even cheaper; $1 / 4$ a Pound. Currently, the ticket price of the SG is 10 Egyptian Pounds, and the DG, al-Fustat Park and the Aquarium Grotto entrance tickets cost 5 Egyptian Pounds. These parks are the cheapest in the city where the cost of a ticket 


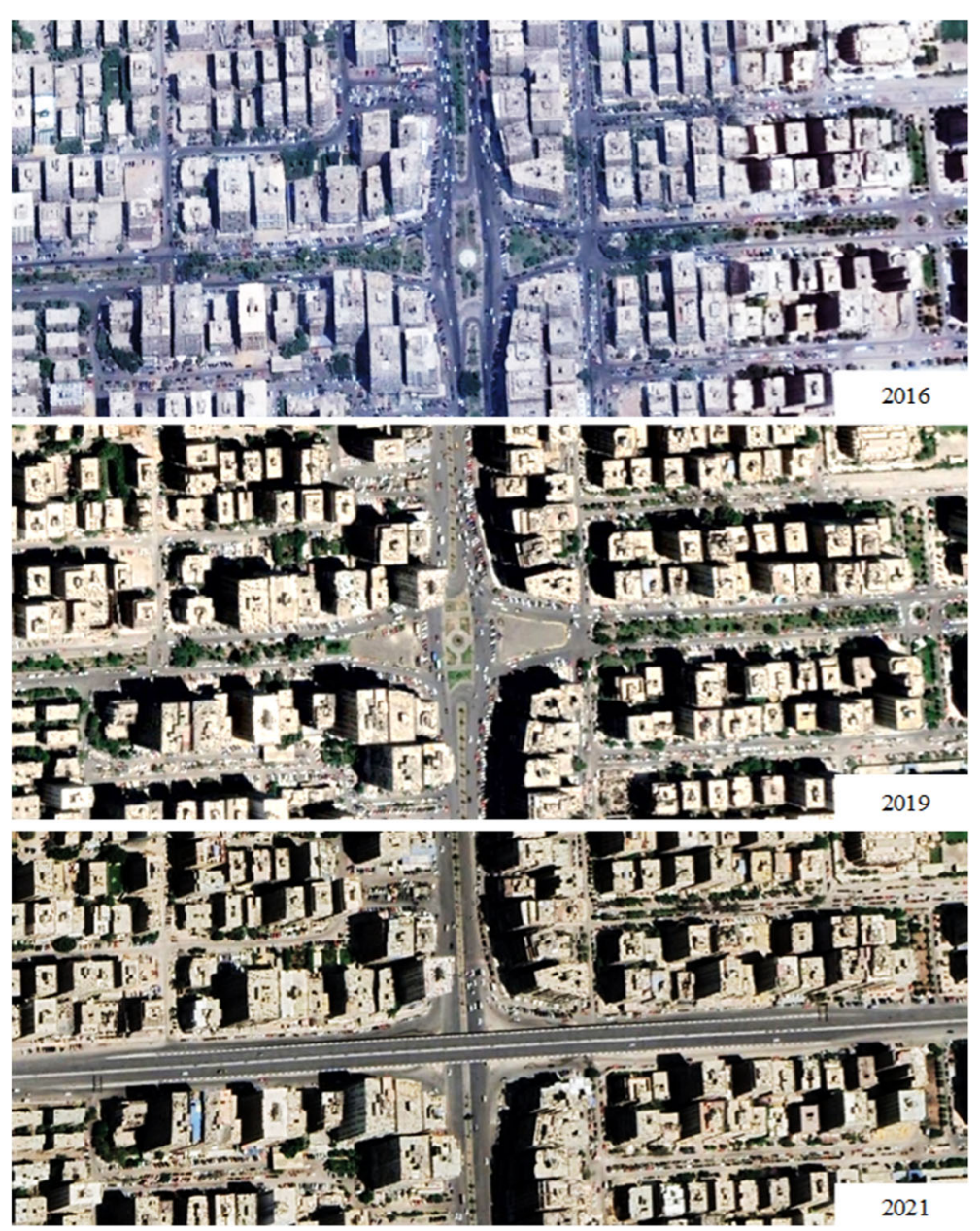

Fig. 10 Intersection of Abbas al-Aqad Street with al-Batrawy Street, Nasr City, Map data @ 2021 Google

for other parks can reach between 15 to 40 Egyptian Pounds. Not only did tickets prices rise significantly, but also activities that require additional costs kept increasing and became the main focus of the management.

Cairo needs to restore the proper role of green spaces and public parks and stop their continuous loss. An improved public and urban life requires the integration of public green spaces into the experience of any city. Increasing the number of existing green spaces and achieving a better distribution throughout the city would reduce the pressure on existing spaces and facilitate access to spaces closer to more residents. Enhancing management and maintenance practices in existing green spaces and public parks would improve their quality and encourage more people to use them.

\section{Lack and fragmentation of data}

Accurate and comprehensive data that document and categorise existing green spaces are important in supporting planning and decision-making to effectively manage and develop green spaces [17]. Cairo lacks the support of an accurate publicly accessible geographical database for all its green spaces areas, locations and categorisation. CCBA 


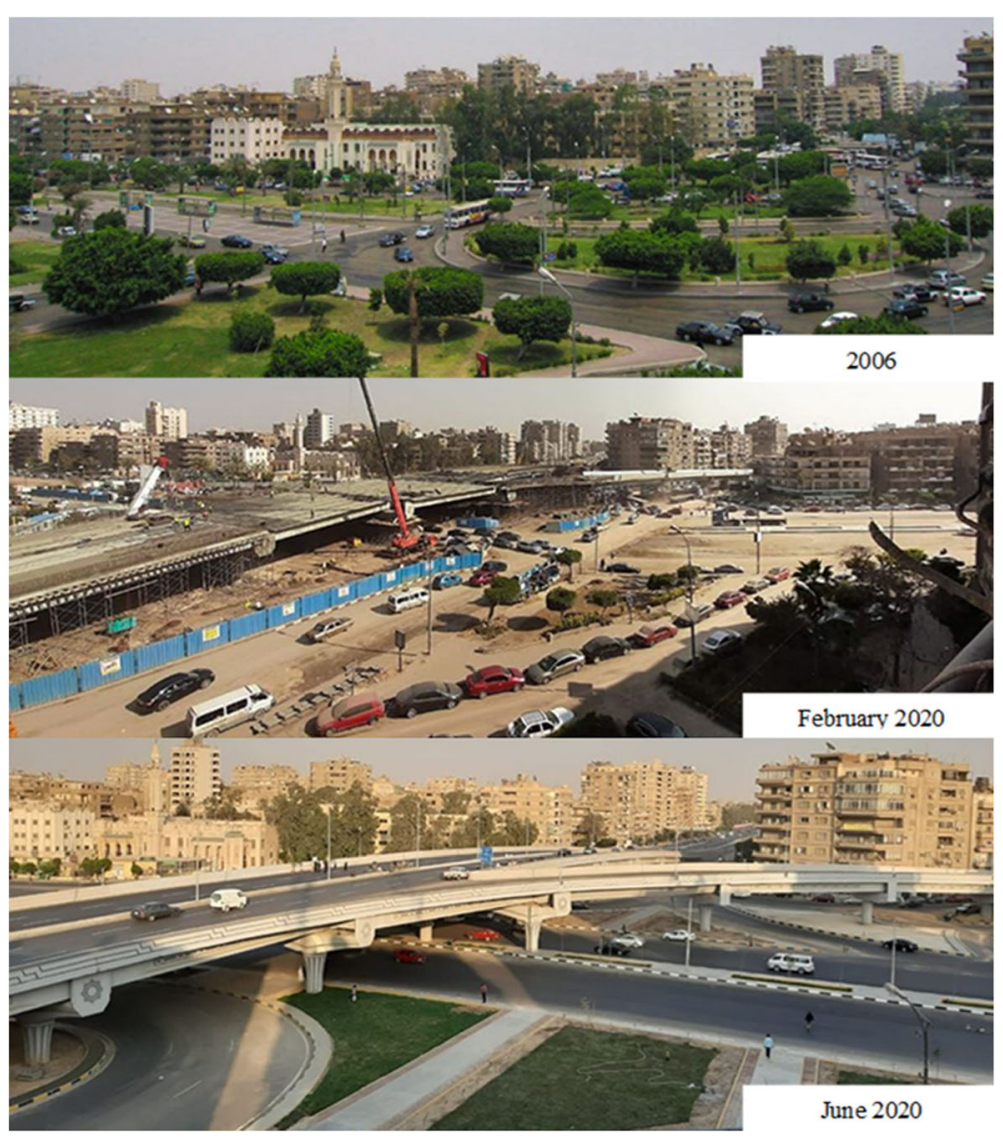

Fig. 11 al-Higaz Square, Heliopolis, Photos by Essam Arafa

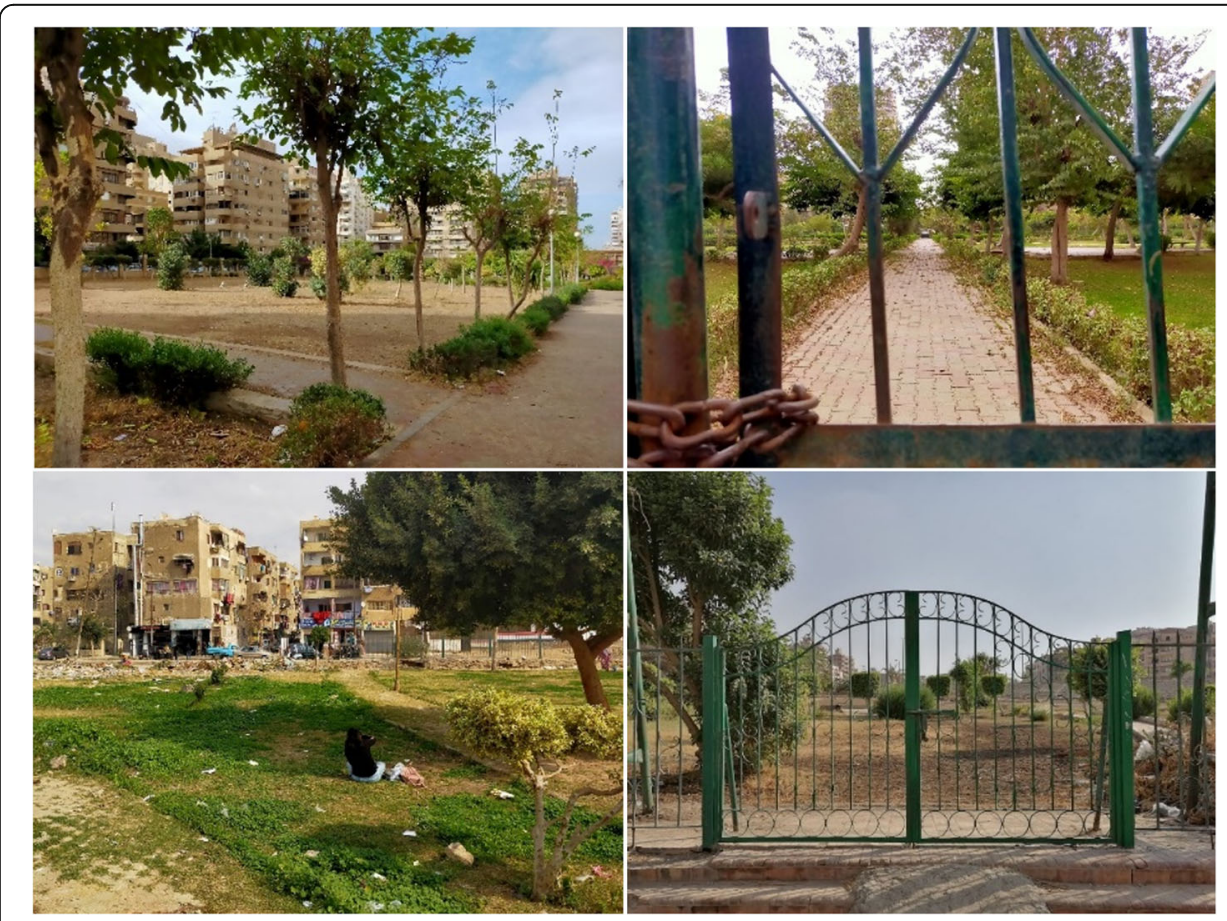

Fig. 12 Examples of closed/deteriorated amenity green spaces, Nasr City and al-Mokattam 


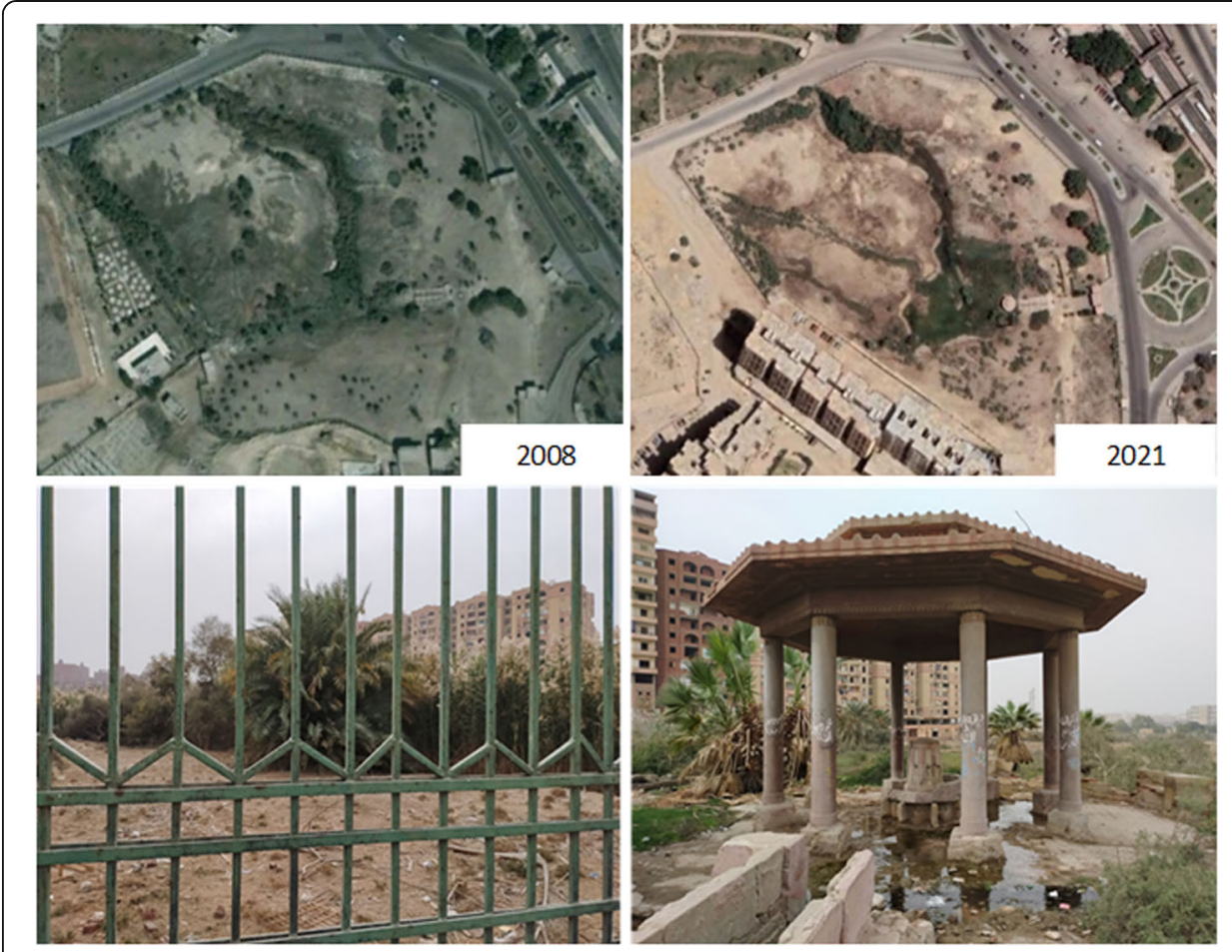

Fig. 13 The closed and deteriorated Ain Helwan Park, Helwan District-Top images Map data $\odot$ 2021 Google

does not have a clear methodology in creating its database. They do not follow up on yearly changes and take decisions accordingly. Their data also lack a coding for each green space and its exact location. For any improvement of the current situation in Cairo, they need to start determining more accurately the green spaces in each district which will allow better decision-making regarding the required resources, priorities for intervention and goals for preserving and increasing green spaces. Having accurate data can also help communicate the problems they face and also follow-up on achievements or failures in enhancing the quantity of green spaces in each district annually.

CCBA, which is connected to Cairo Governorate, manages most of the green spaces in Cairo with branches in each of the city's districts. It also manages a number of parks through its DG Administration. The responsibility for managing other public parks and types of green spaces lies under several other agencies and administrations. With this fragmentation of management responsibilities, Cairo's green spaces and public parks do not have a proper classification that reflects their features. They are classified based on their management authority like SG and DG. The only common factor between most of these parks is their administration, but they differ in their areas and characteristics.

As a result, green spaces and public parks in Cairo are often isolated from one another and from other functions. They are not managed as a connected network which undermines their abilities to provide different benefits [17]. Integration between parks is not found between those under the same management let alone between parks managed by different administrations or between governmental agencies. Different public entities prefer to define the boundaries of their territories and separate their land uses 
from others. So, in Cairo's parks fences are found to separate uses that can be integrated which prevents visual continuity and connectivity between uses.

The fragmentation of even adjacent parks led to having a larger number of parks that are often confined in areas and crowded with activities. For example, at al-Zamalek Island, despite the close proximity of its parks, they are managed individually, and each requires a separate entrance ticket (Fig. 14). Al-Tyfl and 6th of October Parks contain libraries that are surrounded inside the parks by their own fences. Libraries and other public uses, like metro stations, are found also next to some DG but without any

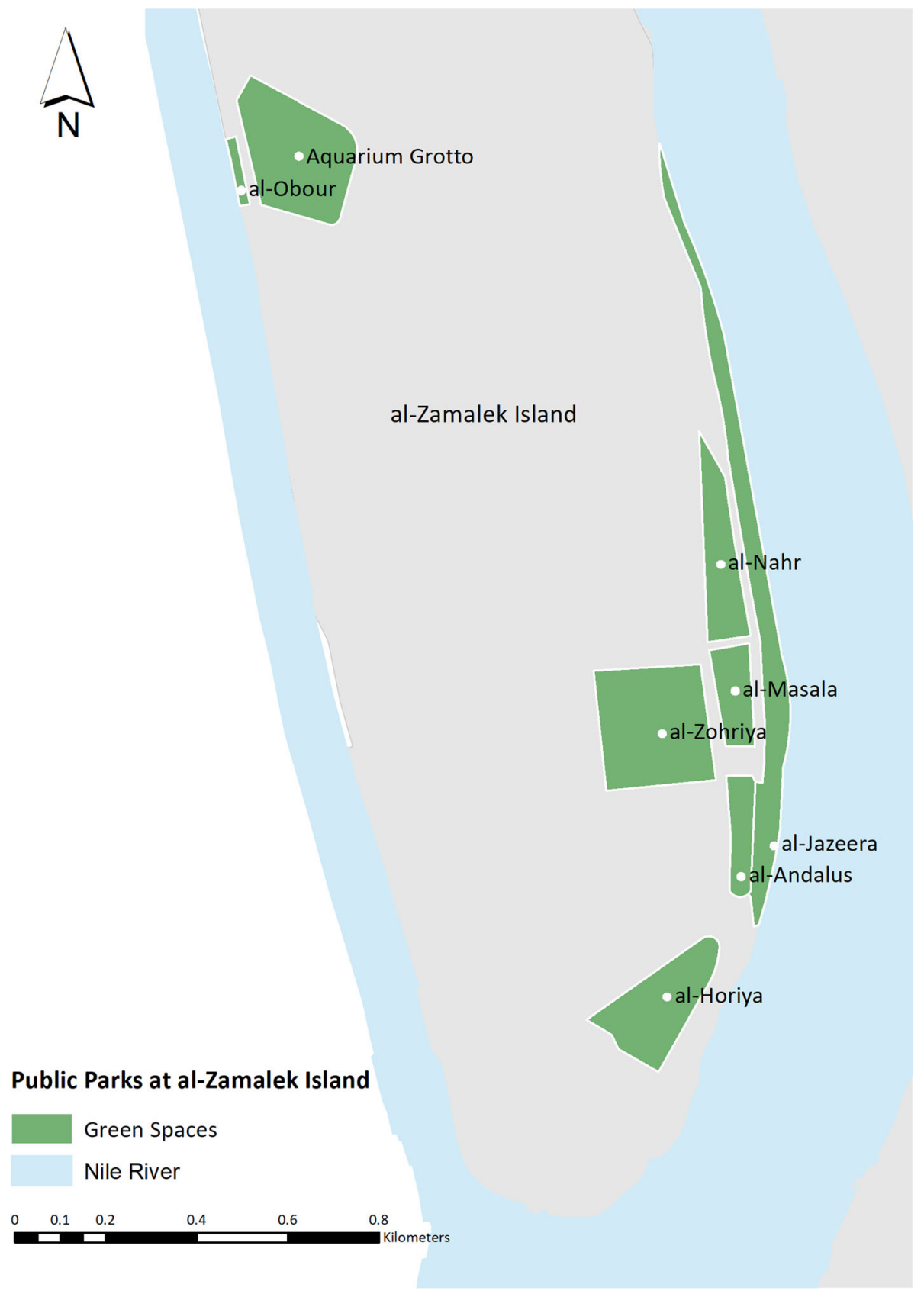

Fig. 14 Fragmentation of Public Parks at al-Zamalek 
connectivity to the parks. Rod al-Farrag Park is separated from the Culture Centre of Rod al-Farrag which is a remarkable building that used to be a part of the old market that the park replaced. Al-Manyal Park is next to Mohammed Aly Palace and gardens, and they are separated by high walls. Similarly, al-Qasr Park is separated from a nearby building that could be renovated and integrated with the park use (Fig. 15).

Moreover, the areas of the parks, if Swanwick et al.'s [26] classification is followed, do not also capture the actual use of the parks, their scale of effect or catchment. DG and

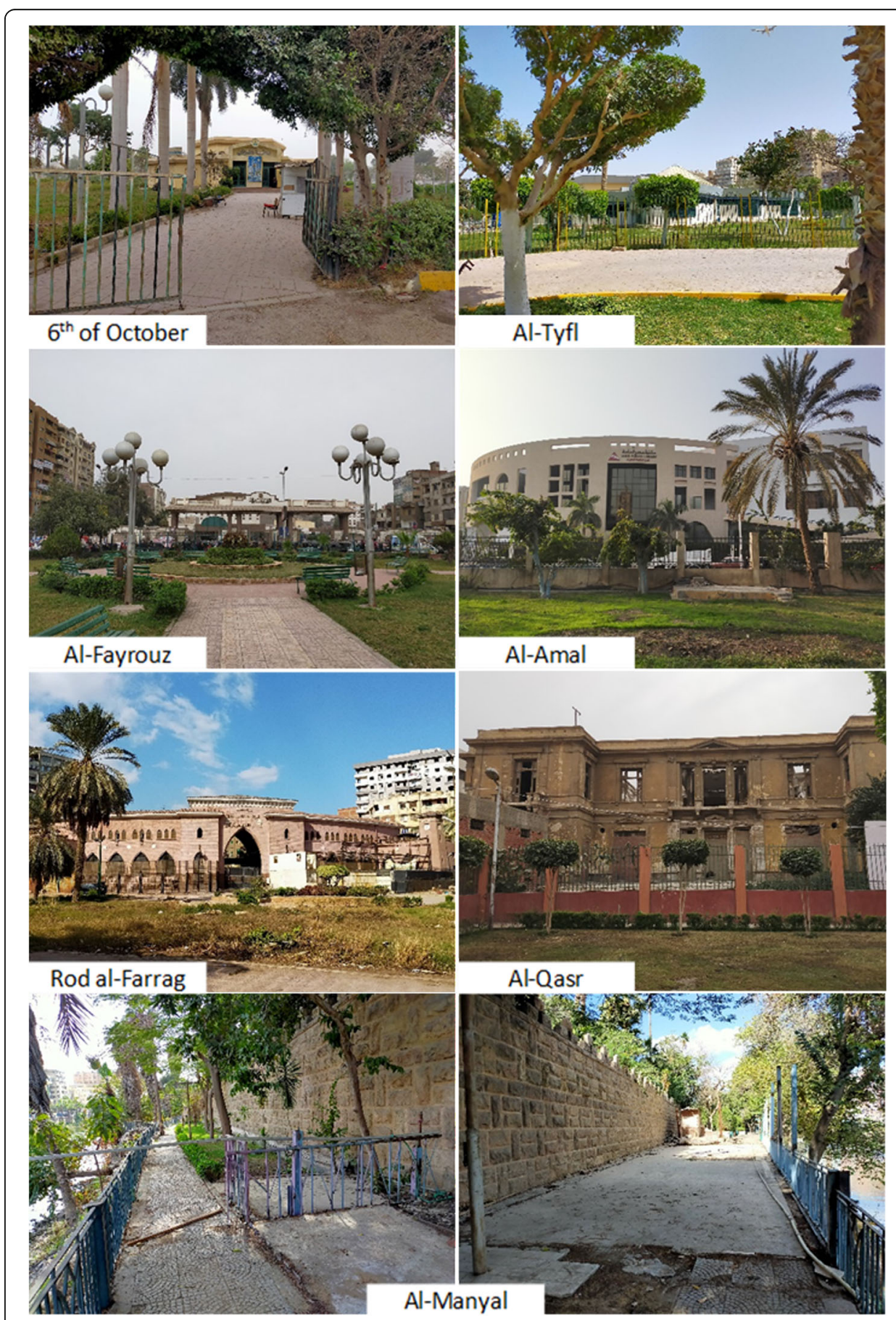

Fig. 15 Separation of uses in Cairo's public parks 
SG often have small parks that are better suited to be a public square or a residential green space. Other parks have wider catchments beyond their area category. These parks attract users from outside the districts either because of a distinctive feature or location, for example, the Aquarium Grotto, um-Kulthum and al-Fonon. Accordingly, a better classification is required that would include all public parks in Cairo.

Finally, dealing with existing data requires close examination in order not to be misled by their interpretation. Kafafy [20] argues that official estimations for green spaces' areas and individual share can be misleading and are not completely reflected in direct benefits to people living in Cairo. Areas that are calculated in these reports include areas inaccessible to the public, undeveloped green spaces, in addition to services and parking areas attached to green spaces [20].

For example, in 2008, Cairo governorate [9] published a report, in collaboration with CCBA, about green spaces in Cairo. The report included an estimation of $1.82 \mathrm{~m}^{2} /$ individual for the year 2007. It also claimed that the individual share in 1997 was $1.2 \mathrm{~m}^{2}$. However, these numbers are not accurately representing the existing green spaces in Cairo. The individual share the report mentioned for 1997 is similar to the original individual share in 2000 mentioned by al-Zafarany [4] indicating that it included youth centres and sports clubs. If compared with the individual share in 2006, it is unlikely that it increased from 1.18 to $1.82 \mathrm{~m}^{2}$ in one year. Also, Shaban [24] showed that the individual Cairenes' share of green spaces was $1.5 \mathrm{~m}^{2}$ in 2006. This value is divided between parks and green spaces, $0.6^{10} \mathrm{~m}^{2}$ /individual, and public clubs and youth centres $0.8 \mathrm{~m}^{2} /$ individual. This shows how adding areas of youth centres and sports clubs changes the data significantly.

Examining the boundaries any data represent is important as it could provide misinformation as well. The changes in the administrative boundaries of Cairo's districts shift the individual share of green spaces significantly and disparities happen between two adjacent areas that were considered formally as one district. For example, al-Maadi has one of the highest individual shares of green spaces in Cairo while Tora is amongst the lowest. In the early 2000s, they used to be one district. If their share is to be calculated together for the year 2020, al-Maadi and Tora will have $1.53 \mathrm{~m}^{2}$ /individual, while each of them separately has an individual share of 5.27 and 0.09 respectively. Similarly, in Gharb al-Qahira that has the highest individual share in $2020\left(10.04 \mathrm{~m}^{2}\right)$, its individual share would drop to $3.66 \mathrm{~m}^{2}$ if calculated with Boulaq that has $0.28 \mathrm{~m}^{2} /$ individual.

\section{Conclusions}

For several years, the urban fabric and character of Cairo have significantly changed. Green spaces have often been the easiest to be sacrificed and replaced with other functions. This article documented the quantities and distribution of green spaces and public parks in Cairo trying to shed the light at the critical situation the city currently faces. Over the years, the quantity and distribution of green spaces and public parks in Cairo have not complied with the national or international standards. In addition, Cairo has lost significant quantities of green spaces in the past few years and the quality of others has seriously deteriorated. Green spaces and public parks in Cairo are managed

\footnotetext{
${ }^{10}$ The value is different from the calculated value in this article because, as mentioned earlier, the calculation in Shaban's [24] thesis excluded some of the districts that were not part of Cairo at the time he did his investigation.
} 
with a very limited perspective of their wide influence and the benefits they can provide. They are being treated as vacant lands that can be exploited by any means possible to increase the income they can bring or be easily replaced with other functions. A more sustainable approach to development and a shift from the current dominating view of green space as a low priority are required. Otherwise, the downward trend in green spaces' areas and individual share of green spaces will carry on which will continue to have serious environmental consequences, damaging the image of the city, its character and the quality of life of its residents. Planning and management of green spaces in Cairo also require a more integrative approach that starts with creating comprehensive data for green spaces including their quantities, distribution and a new categorisation for their types to support the planning and management of green spaces.

\section{Abbreviations}

GOPP: General organisation for physical planning; CAPMAS: Central agency for public mobilization and statistics; GIS: Geographical information system; CCBA: Cairo cleaning and beautification agency; DG: Distinctive gardens; SG: Specialised gardens; CPC: Cultural park for children; AKDN: Aga Khan development network; CCCC: Child centre of civilization and creativity; GCR: Greater Cairo Region; NOUH: National organisation for urban harmony

\section{Supplementary Information}

The online version contains supplementary material available at https://doi.org/10.1186/s44147-021-00067-z.

Additional file 1. Supplementary Information.

\section{Acknowledgements}

Not applicable.

\section{Authors' contributions}

The corresponding author, D.A., collected and analysed the data and wrote the first draft of the article. B.D., the first supervisor of D.A. PhD, supervised the planned research, reviewed and edited the article. The authors read and approved the final manuscript.

Funding

The researcher [Dalia Aly] is funded by a full scholarship [MM5/19] from the Ministry of Higher Education of the Arab Republic of Egypt.

Availability of data and materials

The data relevant to the article are included in tables, graphs and maps within the article and as Supplementary materials.

\section{Declarations}

Ethics approval and consent to participate

Not applicable.

Consent for publication

Not applicable.

\section{Competing interests}

The authors declare that they have no competing interests.

Received: 24 August 2021 Accepted: 21 December 2021

Published online: 01 February 2022

\section{References}

1. AKDN (2010) Cultural Park for Children. https:/www.akdn.org/architecture/project/cultural-park-children. Accessed 6 June 2021

2. AKDN (2018) Creating an Urban Oasis: al-Azhar Park, Cairo, Egypt. https://www.akdn.org/gallery/creating-urban-oasis-al-a zhar-park-cairo-egypt. Accessed 6 June 2021

3. Al-Messiri N (2004) A Changing Perception of Public Gardens. In: Bianca S, Jodidio P (eds) Cairo: revitalising a historic metropolis. Aga Khan Trust for Culture, Turin, pp 221-233

4. Al-Zafarany A (2004) Existing green areas in Cairo: comparison with planning criteria and international norms. In: AlAzhar University Engineering Conference. Al-Azhar University, Cairo

5. Al-Zamley A (2006) Green areas in Cairo. In: Arab Cities Development Conference. The GOPP and the Arab League Council, Cairo, pp 24-26 
6. Almoghazy A (2020) New roads, bad connections: how new road projects impact the right to the city. In: Altern. Policy Solut shorturl.at/pzClZ. Accessed 25 Jul 2021

7. Araby M El (2002) Urban growth and environmental degradation: the case of Cairo, Egypt. Cities 19(6):389-400. https:// doi.org/10.1016/S0264-2751(02)00069-0

8. Ashoub S, Elkhateeb MW (2021) Enclaving the city; new models of containing the urban populations: a case study of Cairo. Urban Plan 6:202-2017. https://doi.org/10.17645/up.v6i2.3880

9. Cairo Governorate (2008) Cairo parks. Extended Green. Cairo Governorate, Cairo

10. Cairo Governorate Portal (2021) Statistics and indicators. http://www.cairo.gov.eg/ar/Pages/Statistics.aspx?SubmID=31. Accessed 18 Feb 2021

11. CAPMAS (2020) Annual statistics book. https:/www.capmas.gov.eg/Pages/StaticPages.aspx?page_id=5034. Accessed 15 Aug 2021

12. CAPMAS (2017) Final results of the 2017 general census for population, housing and establishments: population and housing circumstances. https://www.capmas.gov.eg/Pages/Publications.aspx?page_id=5104\&YearlD=23401\&Year=23598. Accessed 4 Feb 2021

13. CAPMAS (2008) Final results of the 2006 general census for population and housing circumstances. https://www.capma s.gov.eg/Pages/Publications.aspx?page_id=5104\&YearlD=23401\&Year=23598. Accessed 4 Feb 2021

14. Egypt's Projects Map (2021) Development of Merryland Park. https://egy-map.com/project/تطوير-حديقة_المبريلاند. Accessed 6 June 2021

15. Evert K-J, Ballard EB, Elsworth DJ et al (eds) (2010) Encyclopedic dictionary of landscape and urban planning. Springer Berlin Heidelberg, Berlin

16. Farinha-Marques $P$, Lameiras JM, Fernandes $C$ et al (2011) Urban biodiversity: a review of current concepts and contributions to multidisciplinary approaches. Innov Eur J Soc Sci Res 24:247-271. https://doi.org/10.1080/13511610.2 011.592062

17. Feltynowski M, Kronenberg J, Bergier T et al (2018) Challenges of urban green space management in the face of using inadequate data. Urban For Urban Green 31:56-66. https://doi.org/10.1016/j.ufug.2017.12.003

18. Gairola S, Noresah MS (2010) Emerging trend of urban green space research and the implications for safeguarding biodiversity: a viewpoint. Nat Sci 8:43-49

19. Harabech H, Farid F (2020) Cairo's green lung razed for roads to new desert capital. In: AFP shorturl.at/tAGQZ. Accessed 8 June 2021

20. Kafafy N (2010) The dynamics of urban green space in an arid city: the case of Cairo-Egypt. Cardiff University, Cardiff

21. Karayannis G (2014) Dissecting ISO 37120: Why shady planning is good for smart cities. In: Smart Cities Counc https:// smartcitiescouncil.com/article/dissecting-iso-37120-why-shady-planning-good-smart-cities. Accessed 13 July 2019

22. Lindsey U (2017) The anti-Cairo. Places J. https://doi.org/10.22269/170314

23. Raymond A (2000) Cairo. Harvard University Press, Cambridge

24. Shaban A (2009) Redevelopment of public green spaces network in Cairo City. Cairo University, Cairo

25. SIS (2017) The Aquarium Grotto Park. https://www.sis.gov.eg/Story/115978/حيقة_الأسماك-او-حديقة-جبلاية_الأسماك/Clang=ar. Accessed 6 Jun 2021

26. Swanwick C, Dunnett N, Woolley H (2003) Nature, role and value of green space in towns and cities: an overview. Built Environ 29:94-106

27. The GOPP (2012) Greater Cairo urban development strategy, Part 1: Future vision and strategic direction. The GOPP, Cairo

28. The NOUH (2010) Rules and principles of urban design and landscape of open and green spaces. The NOUH, Cairo

\section{Publisher's Note}

Springer Nature remains neutral with regard to jurisdictional claims in published maps and institutional affiliations.

\section{Submit your manuscript to a SpringerOpen ${ }^{\circ}$ journal and benefit from:}

- Convenient online submission

- Rigorous peer review

- Open access: articles freely available online

High visibility within the field

- Retaining the copyright to your article

Submit your next manuscript at $\boldsymbol{\nabla}$ springeropen.com 